\title{
Isolation, Characterization, and Growth Promotion of Phosphate-Solubilizing Bacteria Associated with Nicotiana Tabacum (Tobacco)
}

\author{
Lin Gao', Fanyu Kong1, Chao Feng', Jing Wang', Jiaming Gao ${ }^{2}$, \\ Guoming Shen', Chengsheng Zhang** \\ ${ }^{1}$ Tobacco Research Institute of Chinese Academy of Agricultural Sciences, Qingdao 266101, PR China \\ ${ }^{2}$ Tobacco Research Institute of Hubei Province, Wuhan 430000, PR China
}

Received: 24 November 2015

Accepted: 16 February 2016

\begin{abstract}
Phosphate-solubilizing bacteria (PSB) increase phosphate bioavailability, thereby reducing the application frequency of chemical fertilizers in the production of Nicotiana tabacum (tobacco). In this study, PSB were isolated from tobacco plants for the first time. These PSB were screened in vitro for their ability to solubilize inorganic $\mathrm{P}(\mathrm{Pi})$ when grown in association with tobacco plants. Thirty-six PSB with the ability to solubilize $\mathrm{P}_{\mathrm{i}}$ were isolated and screened for their indolyl-3-acetic acid and siderophore-producing capabilities. In addition, all 36 PSB strains had a partial fragment of their 16S rRNA gene sequenced. The analysis revealed high sequence identity to $16 \mathrm{~S}$ rDNA sequences from Bacillus, Arthrobacter, Providencia, Enterobacter, Proteus, Psychrobacter, Serratia, Rhodococcus, Pseudomonas, Ochrobactrum, and Acinetobacter. Of the 36 PSB strains analyzed, three (Psychrobacter alimentarius HB15, Enterobacter ludwigii HB21, and Ochrobactrum haematophilum HB36) were selected for a controlled plant inoculation experiment. Inoculation of tobacco plants with these bacterial strains significantly increased plant dry weight. Additionally, inoculation increased $\mathrm{P}, \mathrm{K}$, and $\mathrm{N}$ uptake by tobacco seedlings as well as soil P availability. The increases observed with inoculation were even more pronounced when tricalcium phosphate (TCP) was added to the soil. The phosphate-solubilizing activity of these three strains was correlated with the release of gluconic, tartaric, acetic, and citric organic acids. Overall, co-inoculation of PSB and TCP appears to represent a promising option for increasing the yield of tobacco plants. The adoption of this technique could provide a pathway to reducing fertilizer input in agricultural settings.
\end{abstract}

Keywords: growth promotion, Nicotiana tabacum, phosphate-solubilizing bacteria, Tricalcium phosphate

\section{Introduction}

Phosphorus (P) is an essential macronutrient for the growth and development of plants. Most plants rely on

*e-mail: zhangchengsheng@caas.cn soil for $\mathrm{P}$ uptake. Although soil usually contains high levels of total $\mathrm{P}$, most $\mathrm{P}$ exists in forms that are not soluble or bioavailable (i.e., mineral phosphorous or organic phosphorous) [1]. Low $\mathrm{P}$ availability limits plant growth in many soils across the world and commonly limits agricultural productivity [2]. In China, approximately $74 \%$ of arable land is limited by available P [3], which 
has traditionally been overcome by adding $\mathrm{P}$ fertilizers [4]. However, a large portion of the soluble inorganic phosphate applied to the soil as chemical fertilizer is rapidly immobilized and becomes unavailable to plants [5]. Generally, a few days after fertilization available $\mathrm{P}$ levels reach similar values to those before application [6].

Extensive mining operations exist to meet the current demands for $\mathrm{P}$ as fertilizer, yet some estimates indicate that these mines could be depleted in extractable P by 2060 [7]. In addition to the limited supply of mineable P, the excessive use of chemical fertilizers not only wastes resources, but also leads to environmental pollution [8]. Therefore, it is critical to explore alternative sources for better management of the plant-soil-microbial P cycle to reduce our reliance on chemical fertilizers.

Recently, phosphate-solubilizing bacteria (PSB) have attracted the attention of agriculturists. The addition of PSB is considered an effective method for reducing the frequency of $\mathrm{P}$ fertilizer applications to different crops [910]. PSB functions by converting insoluble phosphates into bioavailable forms via the processes of acidification, exchange reactions, chelation, and production of gluconic acid [11]. In addition, some of these bacterial species may promote plant growth by secreting chemicals such as siderophores and indole acetic acid (IAA) [12-13]. However, an abundance of PSB in soil does not guarantee that they will be able to compete with the microorganisms already established in the rhizosphere. This potential limitation requires the inoculation of plants with PSB to increase their soil density and thereby increase the productivity of agricultural ecosystems [14].

Tobacco is an important cash crop in China and more than one million acres are planted each year [15]. P is one of the key elements needed to improve the yield and quality of tobacco leaves. Currently, the tobacco nutrient supply is mainly provided through the application of $\mathrm{P}$ fertilizers with poor solubility, and the locations where tobacco is grown often have soil with serious nutritional limitations. Although there has been extensive research on PSB [16-21], few studies have investigated their phosphate-solubilizing potential, their biodiversity, or their effects on nutrient uptake in tobacco cultivation. Therefore, we undertook this study to 1) isolate and characterize tobacco PSB and 2) study the effects of PSB on the release of $\mathrm{P}$ from TCP and their effects on tobacco growth. The ultimate goal is to use PSBs as bio-fertilizers in order to improve fertilization in tobacco cultivation and minimize P loss from soils.

\section{Materials and Methods}

\section{Soil Collection and PSB Screening}

Twelve soil samples were collected from the rhizosphere of tobacco fields in Xianfeng County, Hubei Province, China. Soil in this region had the following general properties: $\mathrm{pH} 5.73$, organic $\mathrm{C}$ content $24.47 \mathrm{~g} / \mathrm{kg}$, available $\mathrm{N}$ content $141.72 \mathrm{~g} / \mathrm{kg}$, available P content 26.2 $\mathrm{mg} / \mathrm{kg}$, and available K content $207 \mathrm{mg} / \mathrm{kg}$. Rhizospheric soil was sampled in June 2013, which is the peak growing season for tobacco (variety Yunyan 87). First, a soil profile of 0 to $20 \mathrm{~cm}$ depth was dug, the roots exposed in the profile were cut off, and soil that was loosely bound to the roots was shaken off and collected. Next, soil still attached to roots was removed with a sterilized brush, packed in sterilized paper sacks, and immediately transported to the laboratory for processing.

PSBs were isolated according to the methods of Yang et al. [22]. In short, soil samples were serially diluted and then plated on National Botanical Research Institute phosphate (NBRIP) media. This medium contained $5.0 \mathrm{~g}$ of calcium phosphate (TCP) as the only source of $\mathrm{P}$ [23]. Each plated sample was replicated three times. After incubation at $30^{\circ} \mathrm{C}$ for $120 \mathrm{~h}$, all colonies that formed obvious halo zones were categorized as PSB [22]. The individual PSB colonies identified were then used to inoculate NBRIP plates. After incubation at $30^{\circ} \mathrm{C}$ for 120 $\mathrm{h}$, halo/colony ratios (HD/CD) were calculated.

\section{Phosphate Solubility Assay}

To further analyze the ability of PSB, $100 \mathrm{~mL}$ of liquid NBRIP solution containing $5 \mathrm{~g} / \mathrm{L} \mathrm{TCP}$, iron phosphate, (IP) and aluminum phosphate (AP) as sources of insoluble $\mathrm{P}$ was added into $250-\mathrm{mL}$ flasks, and the flasks with NBRIP solution were sterilized by autoclaving at $0.1 \mathrm{MPa}$ for $20 \mathrm{~min}$. The flasks were cooled and then inoculated with $1 \mathrm{~mL}$ of the PSB culture at a concentration of $10^{6}$ $\mathrm{CFU} / \mathrm{mL}$. First, the flasks were incubated at $150 \mathrm{rpm}$ for $7 \mathrm{~d}$ at $30^{\circ} \mathrm{C}$. The culture was then centrifuged at $10,000 \mathrm{rpm}$ for $20 \mathrm{~min}$. The Mo-Sb anti-spectrophotography method was used to quantify the $\mathrm{pH}$ and soluble $\mathrm{P}$ content of the supernatant [24]. Flasks containing the same volume of the medium without inoculants were established as controls. All treatments were performed in triplicate. The resulting data are presented as the mean \pm standard deviation.

\section{Qualitative Determination of IAA}

IAA was assayed qualitatively according to the method described by Shi et al. [25]. PSB were inoculated in modified Congo red medium with the following components per liter: $0.5 \mathrm{~g} \mathrm{~K}_{2} \mathrm{HPO}_{4} \cdot 3 \mathrm{H}_{2} \mathrm{O}$; $0.2 \mathrm{~g} \mathrm{MgSO}_{4} \cdot 7 \mathrm{H}_{2} \mathrm{O} ; 0.1 \mathrm{~g} \mathrm{NaCl} ; 1 \mathrm{~g}$ yeast extract; $10 \mathrm{~g}$ mannitol; $10 \mathrm{~mL} 0.25 \%$ Congo red; $1 \mathrm{~g} \mathrm{NH}_{4} \mathrm{NO}_{3}$; and $100 \mathrm{mg}$ Tryptophan; and filtered using a sterile $0.2 \mu \mathrm{m}$ Millipore membrane filter. Flasks were incubated for $12 \mathrm{~d}$ at $28^{\circ} \mathrm{C}$ on a rotary shaker $(125 \mathrm{rpm})$. A $100 \mu \mathrm{L}$ bacterial culture was mixed with an equal volume of Salkowski colorimetric reagent, and color change of the mixture was observed after 15 min. PSBs that turned medium pink were considered to be IAA-producing. PSBs that did not cause a color change (i.e., the mixture remained colorless) were considered unable to produce IAA. 


\section{Qualitative Production of Siderophores}

The potential to produce siderophores was qualitatively determined according to the method described by Schwyn and Neilands [26]. Bacterial cultures were spot inoculated onto chrome azurol S agar plates $(10 \mu \mathrm{L}$ with a concentration of approximately $10^{8} \mathrm{CFU} / \mathrm{mL}$ ) and incubated at $28^{\circ} \mathrm{C}$ for $48 \mathrm{~h}$. Development of a yelloworange halo surrounding the colonies was used to indicate siderophore production.

\section{Production of Organic Acids during Phosphate Solubilization by Three Isolates}

Three PSB isolates were grown in triplicate on NBRIP media containing $5.0 \mathrm{~g}$ TCP. The cultures were incubated for three days $\left(28^{\circ} \mathrm{C}, 200 \mathrm{rpm}\right)$. Cultures were then centrifuged for $15 \mathrm{~min}$ at $16,000 \times \mathrm{g}$ and passed through a $0.22-\mu \mathrm{m}$ microporous filter membrane. Organic acids were quantified according to the method described by Liu et al. [27]. The organic acids were quantified based on peak areas of standards. Standards included gluconic, malic, tartaric, acetic, citric, and succinic acids. Each analysis was performed in triplicate.

\section{Phylogenic Analysis of PSB}

16S rDNA sequencing and a phylogenetic analysis was used to identify PSB strains. A bacterial genome extraction kit (Sangon Biotech, Shanghai, China) was used to extract genomic DNA. Genomic DNA was used as a template in conjunction with the primers $27 \mathrm{~F}$ (5'-AGAGTTTGATCCTGGCTCAG-3') and 1492R (5'-GGTTACCTTGTTACGACTT-3') to amplify the 16S rDNA gene of each PSB strain [28]. PCR reactions consisted of $25 \mu \mathrm{L}$ of $2 \times$ Es Taq MasterMix (ComWin Biotech, Beijing, China), $2 \mu \mathrm{L}$ of each primer $(10 \mu \mathrm{M})$, and $2 \mu \mathrm{L}$ of the DNA template. A final volume of $50 \mu \mathrm{L}$ was achieved by adding sterile molecular-grade water. The cycling conditions for PCR were as follows: an initial denaturation for $5 \mathrm{~min}$ at $95^{\circ} \mathrm{C}, 30$ cycles at $95^{\circ} \mathrm{C}$ for $1 \mathrm{~min}$, $55^{\circ} \mathrm{C}$ for $1 \mathrm{~min}, 72^{\circ} \mathrm{C}$ for $1 \mathrm{~min}$, and a final extension at $72^{\circ} \mathrm{C}$ for $10 \mathrm{~min}$. The PCR products obtained were purified via gel extraction (TransGen Biotech, Beijing, China) and then sent to Sangon Biotech Co., Ltd. for sequencing. The obtained sequences were assembled using DNASTAR Lasergene (version 7.1) and then submitted to GenBank for homology analysis using the BLASTn algorithm. PSB and reference sequences were aligned using ClustalX (version 1.83) and were trimmed to a shared length. Phylogenetic analysis was applied to trimmed alignment block via MEGA (version 4.0), employing the methods of neighbor-joining and the Kimura 2-parameter distance with 1,000 bootstrap replicates [29].

\section{Strains and Inoculant Preparation}

Controlled growth trials were performed with three efficient PSB strains (designated as HB15, HB21, and
HB36). Bacterial strains were grown on nutrient agar, and single colonies were then transferred into flasks $(250 \mathrm{~mL})$ that contained nutrient broth. The flasks were placed on a rotating shaker $(150 \mathrm{rpm})$ and the colonies were aerobically grown at $30^{\circ} \mathrm{C}$ for $48 \mathrm{~h}$. The bacterial suspension was then diluted to a final concentration of $10^{8} \mathrm{CFU} / \mathrm{mL}$ with distilled sterile water and the resulting suspension was used to treat tobacco seedlings.

\section{Controlled Plant Growth Experiments}

Controlled growth experiments were carried out using tobacco seedlings in environmental chambers programmed at $28^{\circ} \mathrm{C}, 80 \%$ humidity, and $300 \mu \mathrm{mol} \cdot \mathrm{m}^{-2} \cdot \mathrm{s}^{-1}$ light for $12 \mathrm{~h} /$ day. The soil used in this experiment was taken from Jimo tobacco fields in Qingdao, Shandong Province, then sifted with a 10-mesh sieve and mixed with manure $(3: 1 \mathrm{v} / \mathrm{v})$. The soil used had the following chemical properties: $\mathrm{pH}$ of 6.9 , organic matter content of $16.37 \mathrm{~g} / \mathrm{kg}$, available $\mathrm{N}$ content of $0.12 \mathrm{~g} / \mathrm{kg}$, available P content of $6.45 \mathrm{mg} / \mathrm{kg}$, and available $\mathrm{K}$ content of $54 \mathrm{mg} / \mathrm{kg}$. The soil was then sterilized and half the soil was used for direct planting in pots. The remaining soil was supplemented with TCP at a concentration of $200 \mathrm{mg} / \mathrm{kg}$. Tobacco seedlings (variety Xiaohuangjin 1025 ) with 5-6 true leaves were carefully removed from their pots and the associated soil was removed. $\mathrm{NaOCl}$ was used to surface-sterilize the roots for $10 \mathrm{~min}$ and then the roots were washed three times with sterile water. One seedling was planted in each pot. The pots measured $20 \mathrm{~cm}$ in diameter and $25 \mathrm{~cm}$ in height, and each pot contained $5 \mathrm{~kg}$ soil.

All controlled growth experiments were replicated four times. Each replicate included four seedlings. Tobacco seedlings were inoculated $5 \mathrm{~d}$ after transplantation. Experimental treatments were prepared as follows: 1) control without TCP (-TCP) and without PSB, 2) (-TCP) $+\mathrm{HB} 15,3)(-\mathrm{TCP})+\mathrm{HB} 21,4)(-\mathrm{TCP})+\mathrm{HB} 36,5)$ with only TCP added (+TCP), 6) (+TCP) +HB15, 7) (+TCP) $+\mathrm{HB} 21$, and 8) $(+\mathrm{TCP})+\mathrm{HB} 36$. A syringe was used to apply each isolate. Fifty $\mathrm{mL}$ injections of the prepared bacterial suspension were added to the middle of the seedling roots [18-19]. Fifty $\mathrm{mL}$ of the diluted NA culture with no bacteria was applied to control plants. Thirty days after inoculation, the seedlings and roots were removed from the pots and the soil was rinsed from the roots. The dry weight of the seedlings was then measured.

\section{Analyses of Plant Nutrients}

The plant samples were finely ground after drying at approximately $65^{\circ} \mathrm{C}$ for $48 \mathrm{~h}$. The pulverized samples were used to determine the concentrations of $\mathrm{N}, \mathrm{P}$, and $\mathrm{K}$ in tobacco seedlings according to the method described by $\mathrm{Lu}$ [24]. The total $\mathrm{N}$ concentration was assayed by the sulfuric acid-hydrogen peroxide chromatometry method. The $\mathrm{P}$ concentration was determined using the sulfuric acid-hydrogen peroxide digestion-vanadium molybdenum yellow chromatometry method. The K concentration was 
Table 1. Phosphate-solubilizing capabilities, indole acetic acid (IAA) secretion, and siderophore production by 36 bacteria isolated from tobacco rhizospheric soil.

\begin{tabular}{|c|c|c|c|c|c|c|}
\hline \multirow{2}{*}{ Isolate } & \multirow{2}{*}{ Halo: Colony ratio } & \multicolumn{3}{|c|}{ Solubilized P $(\mathrm{mg} / \mathrm{L})$} & \multirow{2}{*}{ IAA production } & \multirow{2}{*}{ Siderophore production } \\
\hline & & TCP & AP & IP & & \\
\hline HB1 & $1.28 \pm 0.07$ & $87.58 \pm 2.69$ & $69.51 \pm 2.14$ & $57.43 \pm 0.70$ & + & + \\
\hline HB2 & $1.32 \pm 0.03$ & $105.25 \pm 3.16$ & $90.57 \pm 2.08$ & $63.50 \pm 2.05$ & - & - \\
\hline HB3 & $1.67 \pm 0.07$ & $141.77 \pm 2.24$ & $126.16 \pm 4.08$ & $120.62 \pm 3.26$ & + & + \\
\hline HB4 & $1.99 \pm 0.15$ & $195.70 \pm 1.55$ & $36.84 \pm 2.13$ & $27.18 \pm 3.65$ & - & + \\
\hline HB5 & $2.09 \pm 0.21$ & $192.73 \pm 1.94$ & $150.82 \pm 2.75$ & $198.14 \pm 2.94$ & + & - \\
\hline HB6 & $1.51 \pm 0.05$ & $126.97 \pm 2.65$ & $90.51 \pm 1.95$ & $105.17 \pm 2.04$ & - & + \\
\hline HB7 & $1.25 \pm 0.04$ & $48.93 \pm 1.68$ & $72.75 \pm 1.34$ & $90.60 \pm 1.75$ & + & + \\
\hline HB8 & $2.25 \pm 0.15$ & $186.30 \pm 1.64$ & $138.19 \pm 2.96$ & $147.37 \pm 2.21$ & - & - \\
\hline HB9 & $1.29 \pm 0.04$ & $66.97 \pm 2.08$ & $51.31 \pm 1.75$ & $58.35 \pm 2.01$ & - & - \\
\hline HB10 & $1.25 \pm 0.10$ & $54.27 \pm 1.04$ & $66.57 \pm 1.26$ & $67.14 \pm 2.15$ & - & - \\
\hline HB11 & $1.42 \pm 0.09$ & $84.23 \pm 1.51$ & $60.15 \pm 1.24$ & $75.36 \pm 1.85$ & - & + \\
\hline HB12 & $1.14 \pm 0.06$ & $33.20 \pm 1.37$ & $45.29 \pm 1.05$ & $54.42 \pm 1.31$ & + & + \\
\hline HB13 & $2.25 \pm 0.10$ & $174.90 \pm 2.39$ & $150.24 \pm 2.25$ & $144.17 \pm 2.56$ & + & - \\
\hline HB14 & $2.25 \pm 0.15$ & $189.67 \pm 1.34$ & $204.14 \pm 2.63$ & $210.10 \pm 3.22$ & - & + \\
\hline HB15 & $2.61 \pm 0.07$ & $308.3 \pm 4.25$ & $280.03 \pm 3.68$ & $269.08 \pm 4.15$ & + & - \\
\hline HB16 & $2.21 \pm 0.11$ & $174.00 \pm 1.54$ & $150.48 \pm 2.31$ & $147.25 \pm 2.52$ & - & - \\
\hline HB17 & $1.23 \pm 0.04$ & $45.27 \pm 1.56$ & $54.49 \pm 1.51$ & $60.02 \pm 1.18$ & - & + \\
\hline HB18 & $1.92 \pm 0.13$ & $186.00 \pm 1.81$ & $177.66 \pm 2.37$ & $165.73 \pm 2.44$ & - & - \\
\hline HB19 & $1.92 \pm 0.14$ & $174.17 \pm 1.76$ & $186.69 \pm 2.74$ & $188.38 \pm 2.33$ & - & - \\
\hline HB20 & $2.26 \pm 0.11$ & $183.10 \pm 1.39$ & $30.75 \pm 2.28$ & $35.81 \pm 2.62$ & - & + \\
\hline HB21 & $4.83 \pm 0.14$ & $358.1 \pm 4.12$ & $282.18 \pm 3.50$ & $277.30 \pm 3.25$ & + & - \\
\hline HB22 & $1.83 \pm 0.08$ & $141.97 \pm 2.18$ & $156.36 \pm 2.05$ & $165.37 \pm 2.53$ & - & + \\
\hline HB23 & $1.50 \pm 0.11$ & $123.80 \pm 1.30$ & $108.55 \pm 1.84$ & $90.61 \pm 2.45$ & + & + \\
\hline HB24 & $2.10 \pm 0.09$ & $201.00 \pm 2.15$ & $213.44 \pm 2.06$ & $234.35 \pm 3.03$ & - & - \\
\hline HB25 & $1.39 \pm 0.03$ & $75.53 \pm 1.63$ & $66.65 \pm 1.50$ & $60.69 \pm 1.24$ & + & - \\
\hline HB26 & $1.89 \pm 0.10$ & $159.17 \pm 2.41$ & $135.83 \pm 1.75$ & $126.64 \pm 1.91$ & + & + \\
\hline HB27 & $1.94 \pm 0.19$ & $189.33 \pm 2.77$ & $165.37 \pm 2.40$ & $156.81 \pm 2.08$ & - & + \\
\hline HB28 & $1.83 \pm 0.11$ & $171.90 \pm 1.04$ & $210.35 \pm 1.94$ & $234.25 \pm 2.28$ & - & - \\
\hline HB29 & $2.41 \pm 0.16$ & $180.63 \pm 1.80$ & $147.17 \pm 2.05$ & $132.66 \pm 1.83$ & + & - \\
\hline HB30 & $1.77 \pm 0.11$ & $138.97 \pm 1.22$ & $150.36 \pm 2.11$ & $159.71 \pm 2.48$ & - & - \\
\hline HB31 & $1.28 \pm 0.09$ & $60.60 \pm 1.61$ & $51.34 \pm 1.17$ & $45.26 \pm 1.24$ & + & - \\
\hline HB32 & $1.35 \pm 0.03$ & $72.33 \pm 1.27$ & $87.38 \pm 1.95$ & $93.46 \pm 1.85$ & - & + \\
\hline HB33 & $1.57 \pm 0.11$ & $102.00 \pm 2.19$ & $87.75 \pm 1.68$ & $90.59 \pm 2.33$ & - & + \\
\hline HB34 & $2.18 \pm 0.06$ & $141.77 \pm 2.40$ & $120.85 \pm 2.16$ & $114.64 \pm 1.75$ & - & - \\
\hline HB35 & $1.62 \pm 0.06$ & $111.57 \pm 1.36$ & $120.82 \pm 2.41$ & $132.78 \pm 2.09$ & + & + \\
\hline HB36 & $3.27 \pm 0.02$ & $360.18 \pm 3.99$ & $286.63 \pm 3.22$ & $285.41 \pm 3.50$ & + & + \\
\hline $\mathrm{CK}$ & ND & $6.88 \pm 0.12$ & $7.05 \pm 0.21$ & $5.95 \pm 0.18$ & - & - \\
\hline
\end{tabular}

Note: Values are means $\pm \mathrm{SD}(\mathrm{n}=3)$. + : production, - : no production. 
measured using the sulfuric acid-hydrogen peroxide digestion-flame photometric method.

\section{Chemical Properties of Rhizospheric Soil}

To assess the chemical properties of the soil, soil samples from the rhizosphere were aseptically separated from the roots. Extraction of available $\mathrm{P}$ was determined using the bicarbonate method. The quantity of available $\mathrm{P}$ was determined via the Mo-Sb Colorimetry method [24].

\section{Results}

\section{In vitro Phosphate-Solubilizing Activity of PSB Isolates}

Thirty-six PSM isolates were obtained from 12 rhizospheric soils of tobacco grown on NBRIP media (Table 1). After incubating for $5 \mathrm{~d}$ on NBRIP media, PSB isolates generated obvious halo zones surrounding each bacterial colony. These zones indicated the ability to solubilize TCP. The halo zone diameters produced by different isolates ranged from 0.2 to $3.15 \mathrm{~cm}$. Fig. 1 shows the widest halo zones produced by the HB36 strain with a diameter of $3.15 \mathrm{~cm}$. The $\mathrm{HD} / \mathrm{CD}$ values ranged from 1.14 to 4.83 . The HB21 strain exhibited the highest $\mathrm{HD} / \mathrm{CD}$ value.

Isolated PSB showed different affinities for TCP solubilization, ranging from 33.20 to $360.18 \mathrm{mg} / \mathrm{L}$ (Table 1). The concentration of solubilized P from 29 isolates (accounting for $83.33 \%$ of the total) ranged from 50-250 $\mathrm{mg} / \mathrm{L}$ (Fig. 2), whereas three isolates had concentrations under $20 \mathrm{mg} / \mathrm{kg}$. Among these PSB isolates, HB36 had the highest phosphate-solubilizing activity with the amount of $\mathrm{P}$ released into the medium, reaching $360.18 \mathrm{mg} / \mathrm{L}$. Strain $\mathrm{HB} 21$ had the second highest activity, with $358.10 \mathrm{mg} / \mathrm{L}$ of $\mathrm{P}$ released into the growth medium. In control experiments, the $\mathrm{P}$ concentration in the medium was only $6.88 \mathrm{mg} / \mathrm{L}$, indicating that $\mathrm{P}$ release was biologically driven.

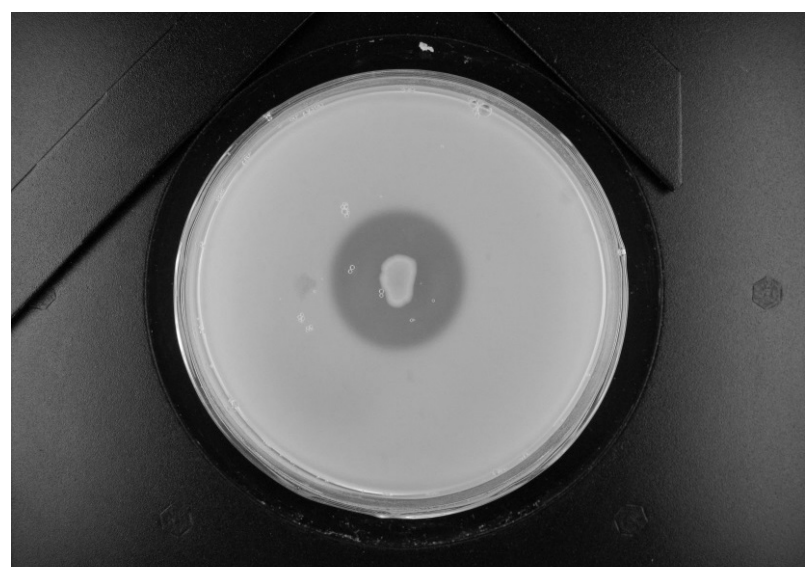

Fig. 1. Phosphate halo of strain HB36 grown on NBRIP culture medium containing TCP $(5 \mathrm{~g} / \mathrm{L})$.

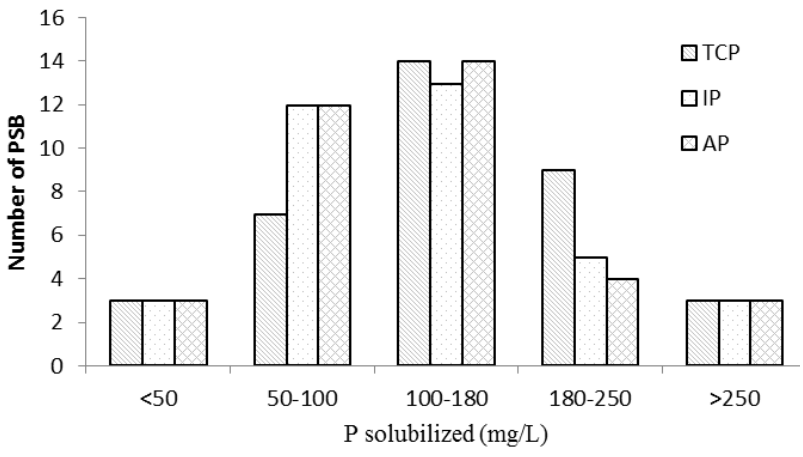

Fig. 2. Distribution of 36 isolated phosphate-solubilizing bacteria (PSB) with different tricalcium phosphate-solubilizing activities.

Twenty-five isolates showed a higher capacity to solubilize TCP compared to AP and IP. The most active isolate solubilized the three insoluble phosphates in the liquid medium, with a maximum activity of 286.63 and $285.41 \mathrm{mg} / \mathrm{L}$ for AP and IP, respectively. Based on these results, we selected the three isolates (HB36, HB21, and HB15) that displayed the highest phosphate solubilization (PS) activities for additional testing.

\section{Production of IAA and Siderophores}

The isolates were screened for additional plant growthpromoting attributes, including IAA and siderophore production (Table 1). Fifteen isolates $(41.7 \%)$ were capable of producing IAA. Half of the isolates (18 in total) were capable of producing siderophores, and only eight isolates were capable of producing both IAA and siderophores.

\section{Sequence Analysis of the PSB 16S rRNA Gene}

Gene sequences obtained from the 36 PSB strains were subjected to a genetic analysis of their $16 \mathrm{~S}$ rDNA. The results revealed a high sequence similarity to bacteria belonging to the families Enterobacteriaceae, Moraxellaceae, Pseudomonadaceae, Micrococcaceae, Brucellaceae, Nocardiaceae, and Bacillaceae. Eighteen isolates $(50 \%$ of the total) were closely affiliated with Bacillaceae (50\%). Enterobacteriaceae had 11 strains, accounting for $30.56 \%$ of the total. The 36 PSB isolates belonged to 11 genera, including Bacillus, Arthrobacter, Providencia, Enterobacter, Proteus, Psychrobacter, Serratia, Rhodococcus, Pseudomonas, Ochrobactrum, and Acinetobacter (Table 2, Fig. 3). The most dominant genus was Bacillus, with 18 PSB isolates, and the dominant species was Bacillus methylotrophicus, with 7 strains.

\section{Nutrient Uptake and Vegetative Growth of Tobacco Seedlings}

The effects of PSB strain inoculations on nutrient uptake and growth parameters of tobacco seedlings are shown in Table 3 . Increases in dry weight ranged from 
Table 2. List of phosphate-solubilizing bacteria isolates and their respective GenBank accession numbers of their partial 16S rRNA gene sequence. The closest phylogenetic affiliation for each sequence is indicated, along with the reference sequence accession number and the percent identity of the isolate sequence when compared to the reference sequence.

\begin{tabular}{|c|c|c|c|c|}
\hline \multirow{2}{*}{ Isolate } & \multirow{2}{*}{$\begin{array}{c}\text { NCBI } \\
\text { Accession number }\end{array}$} & \multicolumn{3}{|c|}{ NCBI BLAST } \\
\hline & & Closest organism & Accession & Identity (\%) \\
\hline HB1 & KC764961 & Bacillus megaterium & JX312585 & 99 \\
\hline HB2 & KC764964 & Arthrobacter chlorophenolicus & FJ577502 & 99 \\
\hline HB3 & KC764970 & Bacillus subtilis & EU931563 & 99 \\
\hline HB4 & KC764972 & Bacillus methylotrophicus & JN700125 & 99 \\
\hline HB5 & KM659215 & Bacillus methylotrophicus & JN700125 & 99 \\
\hline HB6 & KC764973 & Providencia rettgeri & HQ844461 & 99 \\
\hline HB7 & KM659216 & Bacillus subtilis & EU931563 & 99 \\
\hline HB8 & KM659217 & Bacillus subtilis & JF775416 & 99 \\
\hline HB9 & KM659218 & Bacillus subtilis & JQ579620 & 99 \\
\hline HB10 & KC764978 & Enterobacter cloacae & JQ435862 & 99 \\
\hline HB11 & KM659219 & Bacillus methylotrophicus & JN700125 & 99 \\
\hline HB12 & KM659220 & Bacillus methylotrophicus & JF899281 & 99 \\
\hline HB13 & KC764983 & Proteus penneri & HQ259936 & 99 \\
\hline HB14 & KM659221 & Providencia rettgeri & JX871330 & 99 \\
\hline HB15 & KC881247 & Psychrobacter alimentarius & JX514419 & 99 \\
\hline HB16 & KM659222 & Proteus penneri & HQ259936 & 99 \\
\hline HB17 & KM659223 & Providencia rettgeri & JX871330 & 99 \\
\hline HB18 & KC764986 & Acinetobacter johnsonii & EU977664 & 99 \\
\hline HB19 & KC764987 & Serratia marcescens & GQ351502 & 99 \\
\hline HB20 & KC764988 & Bacillus aryabhattai & HQ242772 & 99 \\
\hline HB21 & $\mathrm{KC} 881248$ & Enterobacter ludwigii & GQ915080 & 99 \\
\hline $\mathrm{HB} 22$ & KM659224 & Bacillus megaterium & EU333886 & 99 \\
\hline HB23 & KC764989 & Bacillus pumilus & GQ169785 & 99 \\
\hline HB24 & KM659225 & Bacillus methylotrophicus & JN700125 & 99 \\
\hline HB25 & KM659226 & Bacillus methylotrophicus & JN700125 & 99 \\
\hline HB26 & KM659227 & Bacillus methylotrophicus & JF899287 & 99 \\
\hline HB27 & KM659228 & Bacillus aryabhattai & JX094945 & 99 \\
\hline HB28 & KM659229 & Arthrobacter chlorophenolicus & FJ577502 & 99 \\
\hline HB29 & KM659230 & Bacillus pumilus & GQ169785 & 99 \\
\hline HB30 & KC764991 & Proteus vulgaris & JF772091 & 99 \\
\hline HB31 & KC764992 & Bacillus simplex & AY833099 & 99 \\
\hline HB32 & KM659231 & Providencia rettgeri & JX871330 & 99 \\
\hline HB33 & KC764993 & Rhodococcus erythropolis & JX010951 & 99 \\
\hline HB34 & KM659232 & Proteus penneri & HQ259936 & 99 \\
\hline HB35 & KC764994 & Pseudomonas geniculata & JX661715 & 99 \\
\hline HB36 & KC881246 & Ochrobactrum haematophilum & HQ171238 & 99 \\
\hline
\end{tabular}


$8.46 \%$ to $48.44 \%$ following inoculation of soil with the strains Psychrobacter alimentarius (HB15), Enterobacter ludwigii (HB21), or Ochrobactrum haematophilum (HB36) compared to seedlings grown in soil that was not inoculated. There were no significant differences in the growth parameters of tobacco seedlings receiving only TCP compared to plants without TCP supplementation. However, the interaction of TCP with HB15, HB21, or HB36 was found to be significant with respect to seedling dry weight. The highest results were observed in soil inoculated with strain HB36 in the presence of TCP.
Inoculating plants with the HB15 and HB21 strains significantly increased $(\mathrm{P}<0.05)$ the total $\mathrm{P}$ concentration of plant seedlings compared to the control. The HB36 strain also increased total $\mathrm{P}$ by $11.81 \%$, although the increases were not statically significant. Inoculation of strains HB15 and HB36 significantly increased total $\mathrm{N}$ and $\mathrm{K}$ in plants, whereas HB21 had no effect on total N. Moreover, soil inoculated with TCP significantly increased seedling uptake of $\mathrm{N}$, $\mathrm{P}$, and $\mathrm{K}$, as compared to the treatments with only PSB or TCP applications. In particular, the application of TCP also significantly increased total N, P, and $\mathrm{K}$ in plants compared with plants not receiving TCP.

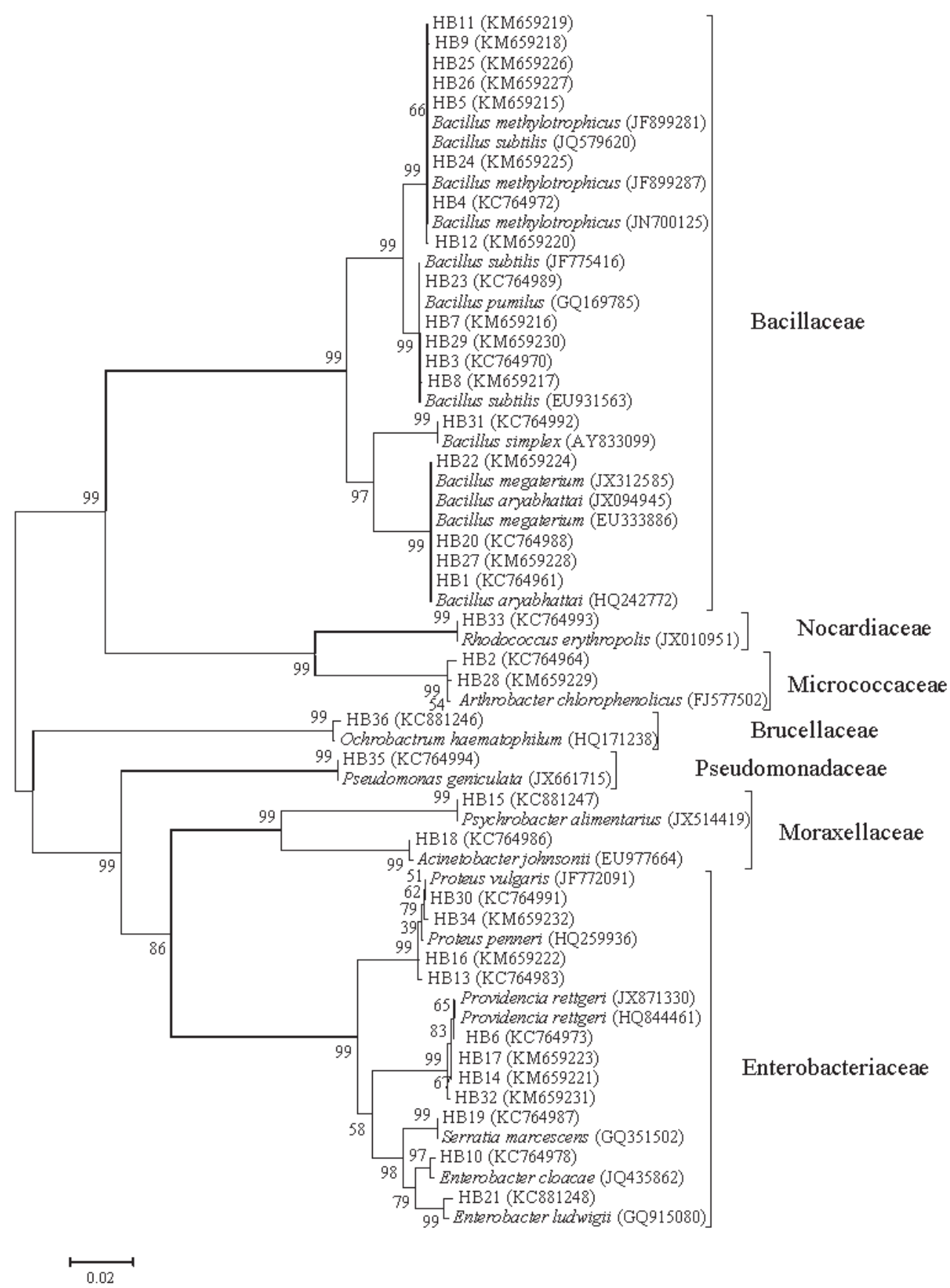

Fig. 3. Phylogenetic tree of phosphate-solubilizing bacteria (PSB) from tobacco rhizospheric soil based on 16S rDNA sequences. All tested isolates had their 16S rDNA gene partially sequenced and were grouped according to genus or species. 
Table 3. Effects of phosphate-solubilizing bacteria on plant growth (measured by dry weight), nutrient uptake, and soil chemical properties.

\begin{tabular}{|c|c|c|c|c|c|}
\hline \multirow{2}{*}{ Treatment } & \multicolumn{4}{|c|}{ Tobacco seedlings } & Tobacco rhizospheric soil \\
\cline { 2 - 5 } & $\begin{array}{c}\text { Dry weight } \\
(\mathrm{g})\end{array}$ & $\begin{array}{c}\text { Total P uptake } \\
(\mathrm{g} / \mathrm{kg})\end{array}$ & $\begin{array}{c}\text { Total N uptake } \\
(\mathrm{g} / \mathrm{kg})\end{array}$ & $\begin{array}{c}\text { Total K uptake } \\
(\mathrm{g} / \mathrm{kg})\end{array}$ & $\begin{array}{c}\text { Available P } \\
(\mathrm{mg} / \mathrm{kg})\end{array}$ \\
\hline CK & $8.63^{\mathrm{c}}$ & $2.88^{\mathrm{e}}$ & $17.46^{\mathrm{c}}$ & $22.49^{\mathrm{f}}$ & $78.41^{\mathrm{h}}$ \\
\hline HB15 & $9.36^{\mathrm{c}}$ & $3.98^{\mathrm{bc}}$ & $21.52^{\mathrm{b}}$ & $31.43^{\mathrm{de}}$ & $95.17^{\mathrm{g}}$ \\
\hline HB21 & $11.58^{\mathrm{ab}}$ & $3.46^{\mathrm{cd}}$ & $17.25^{\mathrm{c}}$ & $26.52^{\text {ef }}$ & $99.18^{\mathrm{f}}$ \\
\hline HB36 & $12.81^{\mathrm{a}}$ & $3.22^{\mathrm{de}}$ & $22.17^{\mathrm{b}}$ & $35.13^{\mathrm{cd}}$ & $112.77^{\mathrm{e}}$ \\
\hline TCP & $9.79^{\mathrm{cd}}$ & $3.67^{\mathrm{cd}}$ & $30.84^{\mathrm{b}}$ & $37.68^{\mathrm{c}}$ & $124.58^{\mathrm{d}}$ \\
\hline TCP + HB15 & $12.80^{\mathrm{a}}$ & $4.81^{\mathrm{a}}$ & $37.52^{\mathrm{a}}$ & $43.86^{\mathrm{b}}$ & $163.40^{\mathrm{c}}$ \\
\hline TCP +HB21 & $12.70^{\mathrm{a}}$ & $4.25^{\mathrm{ab}}$ & $38.93^{\mathrm{a}}$ & $52.90^{\mathrm{a}}$ & $172.19^{\mathrm{a}}$ \\
\hline TCP+HB36 & $13.32^{\mathrm{a}}$ & $4.64^{\mathrm{a}}$ & $36.09^{\mathrm{a}}$ & $46.15^{\mathrm{b}}$ & $168.05^{\mathrm{b}}$ \\
\hline
\end{tabular}

Note: Values represent means of three replications. Means within columns followed by a different lowercase letter are significantly different according to Fisher's protected LSD test at $\mathrm{P} \leq 0.05$.

\section{Changes in Available P in Tobacco Rhizospheric Soil}

The available $\mathrm{P}$ content in tobacco rhizospheric soil substantially increased in treatments receiving both TCP and PSB as compared to the control (Table 3). Applications of TCP and PSB inoculations resulted in higher concentrations of available $\mathrm{P}$ compared to the soil inoculated with PSB without TCP.

\section{Organic Acid Production in Broth Culture}

Culture filtrates were subjected to HPLC analysis. The results indicated the presence of gluconic, tartaric, acetic, and citric organic acids. Among these acids, gluconic acid was produced in high amounts by strains HB15, HB21, and HB36 with concentrations of 5.76, 6.35, and $9.17 \mathrm{mg} \mathrm{L}^{-1}$, respectively. Strains HB21 and HB36 possessed the ability to produce all four acids, while HB15 produced all but citric acid. Furthermore, strain HB36 possessed the highest capacity for organic acid production with an average total organic acid concentration of $18.91 \mathrm{mg} / \mathrm{L}$. The details of organic acid production are given in Table 4.

\section{Correlation Matrix}

Significant correlations were observed between plant dry weight and both available $\mathrm{P}$ in soil and nutrient uptake by tobacco. Significant positive correlations were observed between the amount of available $\mathrm{P}$ in the soil and $\mathrm{N}(\mathrm{r}=0.97), \mathrm{P}(\mathrm{r}=0.85)$, and $\mathrm{K}(\mathrm{r}=0.82)$ uptake in plants. Similarly, plant dry weight was positively correlated with P uptake $(\mathrm{r}=0.55)$ and available $\mathrm{P}$ in soil $(\mathrm{r}=0.78)$. Furthermore, $\mathrm{P}$ solubilization was positively correlated with the secretion of organic acids $(r=0.72)$.

\section{Discussion}

PSB performs an important ecological function in the soil rhizosphere by solubilizing P. Due to their ability to increase crop P availability, rhizosphere PSB inoculants have been proposed for use in integrated nutrient management systems [30-31]. Although PSBs have been successfully isolated from different plants [30-32], very little information on the PSB associated with tobacco has been reported to date.

In this study, 36 PSB strains were screened from tobacco rhizospheric soils and were characterized as belonging to the families Enterobacteriaceae, Moraxellaceae, Pseudomonadaceae, Brucellaceae, Micrococcaceae, Nocardiaceae, and Bacillaceae. Most of the genera in these families have been reported to solubilize phosphate $[4,17]$. The results of prior research concluded that PSB of the genus Pseudomonas were dominant in various soils [21]. However, in the present study the most dominant

Table 4. Quality and variety of organic acids produced by three phosphate-solubilizing bacterial strains.

\begin{tabular}{|c|c|c|c|c|c|c|c|}
\hline \multirow{2}{*}{ Strain number } & \multicolumn{5}{|c|}{ Organic acids $(\mathrm{g} / \mathrm{L})$} & Total organic acids \\
& Tartaric acid & Malic acid & Gluconic acid & Acetic acid & Citric acid & Succinic acid & (g) \\
\hline HB15 & 2.75 & - & 5.76 & 2.23 & - & - & $10.74 \mathrm{Bb}$ \\
\hline HB21 & 3.85 & - & 6.35 & 0.93 & 1.65 & - & $12.77 \mathrm{Bb}$ \\
\hline HB52 & 3.87 & - & 9.17 & 3.59 & 2.27 & - & $18.91 \mathrm{Aa}$ \\
\hline
\end{tabular}


genus associated with tobacco (as identified using cultivation methods) was found to be Bacillus, whereas only one PSB strain affiliated with Pseudomonas was isolated. This may indicate that different species of PSB are specifically adapted to associate with different plant types or soil conditions. In addition, Bacillus has been reported to be among the most dominant groups within PSB populations [17].

The three isolates that were closely affiliated with Psychrobacter alimentarius (HB15), Ochrobactrum haematophilum (HB36), and Enterobacter ludwigii (HB21) showed maximum phosphate solubilization activity. These strains were identified as promising PSB that occur in the tobacco rhizosphere. Previous reports have shown that each of these species associates with plant rhizospheres, and they have been studied as promising PSB [33-35]. Similar to previous reports [12, 13, 33], siderophore production and IAA secretion abilities were observed for many PSB isolates in our work.

Previous studies have demonstrated that PSBs have the ability to promote plant growth [36-37]. These studies indicated that these bacteria can enhance plant growth and increase plant $\mathrm{P}$ content $[19,38]$, which is consistent with the observations made in the present study. Tobacco plants with the lowest dry weights were grown in unfertilized soil that received no TCP and were not inoculated. This was likely due to $\mathrm{P}$ deficiency in the soil used to grow these seedlings. The addition of TCP, as well as PSB inoculation, increased biomass yield relative to the control treatment, indicating that inoculation of PSB strains enhanced biomass, presumably by solubilizing soil P. It is also possible that the enhanced growth of tobacco plants in the presence of PSB is due to the strains' ability to secrete siderophores.

The combined application of TCP with PSB enhanced the uptake of $\mathrm{P}, \mathrm{K}$, and $\mathrm{N}$ by tobacco seedlings more than the control treatment. These results are consistent with those from the growth chamber and greenhouse experiments $[14,22,39]$. In addition, our results agree with those of Yang et al. [22] and Estrada et al. [36], who reported increases in plant dry weight, as well as $\mathrm{P}$ and $\mathrm{N}$ uptake, following an application of PSB combined with TCP as compared to PSB alone.

Our results indicate that various treatments had the potential to enhance available $P$ and thereby directly affect tobacco growth and nutrient uptake. Maximum available $\mathrm{P}$ was detected with PSB inoculations in conjunction with TCP treatments. Our results concur with Singh and Reddy [17], Estrada et al. [36], and Gurdeep and Reddy [21]. Based on the information discussed above, the increased $\mathrm{P}$ concentrations detected in plants inoculated with PSB strains may be attributable to their ability to solubilize inorganic forms of $\mathrm{P}$, thus increasing $\mathrm{P}$ availability in the soil. Correlation analyses showed that tobacco dry weight and N, P, and K content were positively correlated with the available $\mathrm{P}$ content in soil.

The ability of PSB to solubilize mineral phosphates with low solubilities has mainly been attributed to the secretion of organic acids with low molecular weight
[40-41]. For example, gluconic acid is a major organic acid produced by many gram-negative bacteria during phosphate solubilization and is produced by several plant growth-promoting bacteria (PGPB) [27, 42]. Our results also show that $\mathrm{P}$ solubilization was related to the secretion of organic acids.

\section{Conclusions}

Tobacco rhizospheric soils are rich in PSB. Some of these PSB strains demonstrate high phosphate-solubilizing activity and are capable of producing siderophores or IAA. Three PSB strains (HB15, HB21, and HB36) significantly enhanced the dry weight and nutrient uptake by tobacco seedlings. We hypothesize that this was accomplished by increasing the availability of $\mathrm{P}$ and other nutrients in the soil. This effect was more evident in treatments receiving TCP. In addition, the phosphate-solubilizing activity of these three strains was correlated with the release of gluconic, tartaric, acetic, and citric organic acids. Therefore, the results of this study may aid in improving the sustainability of tobacco agriculture via reducing fertilizer input. Further studies are needed to determine the mechanism that PSBs utilize to solubilize TCP and quantify their effectiveness under field conditions.

\section{Acknowledgements}

This research was financially supported by the Agricultural Project of Hubei Province of China (project No. 027Y2012-083).

\section{References}

1. FENG G., ZHANG F., LI X.L., TIAN, C.Y., TANG, C., RENGEL Z. Improved tolerance of maize plants to salt stress by arbuscular mycorrhiza is related to higher accumulation of soluble sugars in roots. Mycorrhiza. 12, 185, 2002.

2. ARCAND M.M., SCHNEIDER K.D. Plant- and microbialbased mechanisms to improve the agronomic effectiveness of phosphate rock: a review. An. Acad. Bras. Ciênc. 78, 791, 2006.

3. HE M.X., GAO Y., HU Z.X., XU Y., LONG R., SUN Q.Y. Screening, identification, and phosphate solubilizing capability of phosphate solubilizing bacterial strain B25. Chinese Journal of Applied Ecology. 1, 235, 2012 [n Chinese].

4. KHAN A.A., JILANI G., AKHTAR M.S., NAQVI S.S., RASHEED M. Phosphorus solubilizing bacteria: occurrence, mechanisms and their role in crop production. J. Agric. Biol. Sci. 1, 48, 2009.

5. HOLFORD I.C.R. Soil phosphorus: its measurement and its uptake byplants. Aust. J. Soil. Res. 35, 227, 1997.

6. SHAROLEY A.N. Phosphorus cycling in unfertilized and fertilized agricultural soils. Soil. Sci. Soc. Am. J. 49, 905, 1985.

7. GILVERT N. The disappearing nutrient. Science. 461, 716, 2009. 
8. CORRELLD.L. The role of phosphorus in the Eutrophication of receiving waters: a review. J. Environ. Qual. 27, 261, 1998.

9. ADESEMOYE A.O., TORBERT H.A., KLOEPPER J.W. Plant growth-promoting rhizobacteria allow reduced application rates of chemical fertilizers. Microb. Ecol. 58, 921, 2009.

10. HIMANI SINGH M. SUDHAKARA REDDY. Effect of inoculation with phosphate solubilizing fungus on growth and nutrient uptake of wheat and maize plants fertilized with rock phosphate in alkaline soils. Eur. J. Soil Biol. 47, 30, 2011.

11. GULATI A., SHARMAR N., VYAS P., SOOD S., RAHI P., PATHANIA V., PRASAD R. Organic acid production and plant growth promotion as a function of phosphate solubilization by Acinetobacter rhizosphaerae strain BIHB 723 isolated from the cold deserts of the trans-Himalayas. Arch.. Microbiol. 192, 975, 2010.

12. MAY Y., RAJKUMAR M., FREITAS H. Improvement of plant growth and nickel uptake by nickel resistant plant growth promoting bacteria. J. Hazard. Mater. 166, 1154, 2009.

13. ZHAO L., TENG S., LIU Y. Characterization of a versatile rhizospheric organism from cucumber identified as Ochrobactrum haematophilum. J. Basic. Microbiol 52, 232, 2012.

14. TAURIAN T., ANZUAY M.S., ANGELINI J.G., TONELLI M.L., LUDUENA L., PENA D., IBANEZ F., FABRA A. Phosphate-solubilizing peanut associated bacteria: Screening for plant growth promoting activities. Plant Soil. 329,421, 2010.

15. ZHU Z. Current status and prospect of tobacco leaf production and researchin China. Acta Tabacaria Sinica .14, 70, 2008 [In Chinese].

16. VASSILEV N., REQUENA A.R., NIETO L.M., NIKOLAEVA I., VASSILEVA M. Production of manganese peroxidase by Phanerochaete chrisosporium grown on medium containing agro-wastes/rock phosphate and biocontrol properties of the final product. Ind. Crop. and Prod. 30, 28, 2009.

17. SINGH H., REDDY M.S. Improvement of wheat and maize crops by inoculating Aspergillus spp. in alkaline soil fertilized with rock phosphate. Arch. Agron. Soil. Sci. 58, $535,2012$.

18. ZHANG L., DING X.D., WANG F., TIAN Z.Y., FENG G. The effects of inoculation with phosphate solubilizing bacteria Bacillus megaterium $\mathrm{C} 4$ in the $\mathrm{AM}$ fungal hyphosphere on soil organic phosphorus mineralization and plant uptake. Acta Ecologica Sinica.13, 4079, 2012 [In Chinese].

19. YU X., LIU X., ZHU T.H., LIU G.H., MAO G. Isolation and characterization of phosphate-solubilizing bacteria from walnut and their effect on growth and phosphorus mobilization. Biol. Fertil. Soils. 47, 437, 2011.

20. ACEVEDO E., GALINDO CASTANEDA T., PRADAA F., NAVIA M., ROMEROA H.M. Phosphate-solubilizing microorganisms associated with the rhizosphere of oil palm (Elaeis guineensis Jacq.) in Colombia. Appl. Soil Ecol. 80, 26, 2014.

21. GURDEEP KAUR M., SUDHAKARA REDDY. Influence of P-solubilizing bacteria on crop yield and soil fertility at multilocational sites. Eur. J. Soil Biol. 61, 35, 2014.

22. YANG P.X., MA Li., CHEN M.H., XI J.Q., HE F., DUAN C.Q., MO M.H., FANG D.H., DUAN Y.Q., YANG F.X. Phosphate solubilizing ability and phylogenetic diversity of bacteria from P-rich soils around Dianchi Lake drainage area of China. Pedosphere. 22, 707, 2012.
23. NAUTIYAL C.S. An efficient microbiological growth medium for screening phosphate solubilizing mecroorganisms. FEMS. Microbiol. Lett. 170, 265, 1999.

24. LU R.K. Analyse Methods of Soil and Agrochemistry. Beijing, China: China Agricultural Science and Technology Press. 1999.

25. SHI S.L., CAO Z.Z., LIU J.R. Study on the phosphate solubilization and plant auxin secretion of Madicago sativa Rhizobium. Acta Prataculturae Sinica. 1, 105, 2007 [In Chinese].

26. SCHWYN B., NEILANDS J. Universal chemical assay for detection and determination of siderophores. Anal. Biochem. 160, 47, 1987.

27. LIU F., LIU H., ZHOU H., DONG Z., BAI X., BAI P., QIAO J. Isolation and characterization of phosphate-solubilizing bacteria from betel nut (Areca catechu) and their effects on plant growth and phosphorus mobilization in tropical soils. Biol. Fertil. Soils. 50, 927, 2014.

28. WILliaM G., SUSAN M., DALE A., DAVID L. 16S ribosomal DNA amplification for phylogenetic study. J Bacteriol. 173, 697, 1991.

29. TAMURA K., DUDLEY J., NEI M., KUMAR S. MEGA4: molecular evolutionary genetics analysis (MEGA) software version 4.0. Mol. Biol. Evol. 24, 1596, 2007.

30. KHAN M.S., ZAIDI A., AHEMAD M., OVES M., WANI P.A. Plant growth promotion by phosphate solubilizing fungi-current perspective. Arch. Agron. Soil. Sci. 56, 73, 2010.

31. RICNARDSON A.E., LYNCH J.P., RYAN P.R., DELHAIZE E., SMITH F.A., SMITH S.E., HARVEY P.R., RYAN M.H., VENEKLAAS E.J., LAMBERS H., OBERSON A., CULVENOR R.A., SIMPSON R.J. Plant and microbial strategies to improve the phosphorus efficiency of agriculture. Plant Soil. 349, 121, 2011.

32. BEHERA B.C., SINGDEVSACHAN S.K., MISHRA R.R., DUTTA S.K., THATOI H.N. Diversity, mechanism and biotechnology of phosphate solubilising microorganism in mangrove-A review. Biocatal. Agr. Biot. 3, 97, 2014.

33. SHOEBITZ M., RIBAUDO C.M., PARDO M.A., CANTORE M.L., CIAMPI L., CURA J.A. Plant growth promoting properties of a strain of Enterobacter ludwigii isolated from Lolium perenne rhizosphere. Soil. Biol. Biochem. 41, 1768, 2009.

34. COLLAVINO M.M., SANSBERRO P.A., MROGINSKI L.A., AGUILAR O.M. Comparison of in vitro solubilization activity of diverse phosphate-solubilizing bacteria native to acid soil and their ability to promote Phaseolus vulgaris growth. Biol. Fertil. Soils. 46, 727, 2010.

35. CALVO P., NELSON L., KLOEPPER J.W. Agricultural uses of plant biostimulants. Plant. Soil. 3,383, 2014.

36. ESTRADA G.A., BALDANI V.L.D., OLIVEIRA D.M., URQUIAGA S., BALDANI J.I. Selection of phosphatesolubilizing diazotrophic Herbaspirillum and Burkholderia strains and their effect on rice crop yield and nutrient uptake. Plant. Soil. 369, 115, 2013.

37. PEREIRA S.I.A., CASTRO P.M.L. Phosphate-solubilizing rhizobacteria enhance Zea mays growth in agricultural P-deficient soils. Ecol. Eng. 73, 526, 2014.

38. BASAK B.B., BISWAS D.R. Co-inoculation of potassium solubilizing and nitrogen fixing bacteria on solubilization of waste mica and their effect on growth promotion and nutrient acquisition by a forage crop. Biol. Fertil. Soils. 46, 641, 2010.

39. GERMAN A.E., VERA L.D.B., DANILO M.O., SEGUNDO U., JOSE I.B. Selection of phosphate-solubilizing diazotrophic Herbaspirillum and Burkholderia strains and 
their effect on rice crop yield and nutrient uptake. Plant Soil. 369, 115, 2013.

40. CHEN Y., REKHA P., ARUN A., SHEN, F., LA W., YOUNG

C. Phosphate solubilizing bacteria from subtropical soil and their tricalcicum phosphate solubilizing abilities. Appl. Soil. Ecol. 34, 33, 2006.

41. BASHANY., KAMNEVA.A, DE-BASHAN L.E. Tricalcium phosphate is inappropriate as a universal selection factor for isolating and testing phosphate-solubilizing bacteria that enhance plant growth: a proposal for an alternative procedure. Biol. Fertil. Soils. 49, 465, 2013.

42. FENDER J.E., BENDER C.M., STELLA N.A., LAHR R.M., KALIVODA E.J., SHANKS R.M.Q. Serratia marcescens quinoprotein glucose dehydrogenase activity mediates medium acidification and inhibition of prodigiosin production by glucose. Appl. Environ. Microbiol. 78, 6225, 2012. 